\title{
How Female Directorship Affect Banks' Profitability - An Application of Threshold Regression Model
}

\author{
T. Thanh Binh Nguyen and Zi-Yu Chen
}

\begin{abstract}
This paper uses the panel data of 26 Taiwanese commercial banks in 1999-2019 to test the relationship between bank female directorship and bank profitability. The main contribution of this paper is to explain whether bank female directors are effective in promoting banks in profitability; and how the relationship between female directorship and bank profitability change when considering their total assets as well as capital adequacy ratios. The model with unknown breakpoints is applied for selecting the best threshold values for testing the asymmetric effect of female directorship on bank performance. We find that Female directorship has an inconsistent effect on bank profits when the capital adequacy ratio is taken into consideration. Banks with high capital adequacy ratio weaken or even reduce the positive relationship between bank female directors and bank profitability. Meanwhile, we also find that banks with total assets higher than TW\$1616 billion have the opposite effect on ROA relative to the rest of banks. This result proves that the estimation of traditional panel regression may not fully present the possible relationships between variables.
\end{abstract}

Index Terms-Taiwanese banks, board structure, female directorship, breakpoints, JEL: G21; G28; G30; G32; G3.

\section{INTRODUCTION}

Corporate social responsibility, starting from a "public interest" perspective, explores what the company should do to "benefit other people as well as oneself". The banking industry is at the core of the country's economic development. The development and performance of banks can reflect the state of the country's economy. The essence of the banking industry is to withstand risks and properly respond to the banking system to benefit the overall society and the national economy. This shows that the degree of profitability and gender diversity in the banking system will help to assist the country's economic development and the implementation of corporate social responsibility.

Currently, the proportion of female directors has been widely concerned for two main reasons; one is the perspective on the equality between men and women, and the other on the value of female directors to firms. More and more policy advisers recommend to stipulate the proportion of female directors, and also emphasize the importance of female directors in corporate governance. There are several questions raised around this issue, such as Do female directors have an impact on corporate performance? Are these effects significant? How many female directors do

Manuscript received April 17, 2020; revised June 22, 2020.

Nguyen Thi Thanh Binh and $\mathrm{Zi}-\mathrm{Yu}$ Chen are with Department of Accounting, Chaoyang University of Technology, 168 Jifong E. Road, Wufong District, Taichung City, 41349, Taiwan (e-mail tbnguyen@cyut.edu.tw, first5201793@gmail.com). firms need to have in order to have an impact on performance? etc...However, there are a limited number of studies on the impact of female board representations in the banking industry in domestic research. Therefore, this study explores whether female directorship has an impact on corporate performance, and how bank size and capital adequacy ratio affect this relationship, aiming to provide reliable recommendations for banking policy and corporate governance in Taiwan.

The threshold regression model with unknown thresholds is applied for selecting the best threshold values for testing the asymmetric effect of female directors on banks' performance. This model describes the nonlinearity and regime shift that occurs when an observed variable crossing unknown thresholds. The empirical findings show that: 1) Female directorship has inconsistent effect on bank profits when the capital adequacy ratio is taken in consideration; 2) Banks with high capital adequacy ratio will weaken or even reduce the positive relationship between bank female directors and bank profitability; 3 ) Banks with total assets higher than TW $\$ 1616$ billion have the opposite effect on ROA relative to the rest of banks; 4) The results of threshold regression prove that the impact of gender diversity on bank profitability is linearity that is more complicated than a direct effect suggests. It is also proved that the estimation of traditional panel regression may not fully present the possible relationships between variables.

The structure of this paper is as follows: The first section is "Introduction", which introduces the motivational purpose and the structure of the article; the second section is "Literature", which review the current trends on the same issue; "Methodology and data" stated in the third section introduces threshold regression, empirical models, variables and sample data of this study; the fourth section is "Empirical results "; and finally "Conclusions".

\section{LITERATURE REVIEW}

A growing number of studies examine how the relationship between gender in the boardroom and corporate governance operates. There are mainly two strands of results on this issue. Many studies show that the female directors on board can have a positive impact on company performance, such as Adler [1] who selects 215 of the US Fortune 500 companies in 1980-1998 as a sample to measure company performance by asset, sales revenue and shareholder income. The study found that companies with a higher percentage of women on the board of directors have $1.6 \%$ and $10.7 \%$ higher in sales revenue and shareholder income, respectively. Carter et al. [2] find that the 
independence of female directors is relatively high because they are more willing to raise some doubts than male directors. However, if the opinions of female directors are excluded by other directors, the relationship between female directors and the company will not be significant. Campbell and Mínguez-Vera [3] investigate the link between the gender diversity and firm financial performance in Spain with panel data analysis, they find that gender diversity has a positive effect on firm value and that the opposite causal relationship is not significant. Rose [4] uses a Danish listed company in 1998-2001 as a research sample to measure female directors from two dimensions: female directors and female directors. The study finds that the proportion of female directors had no significant impact on company value. Bennouri et al. [5] study the relationship between female directorship and firms' ROA, ROE, and Tobin's Q using a sample of 394 French firms for 2001- 2010 period. They find that female directors significantly increase ROA and ROE, and significantly decrease Tobin's Q.

The other strand has the opposite results, such as Hambrick and Jackson [6] who argue that gender diversification can lead to diversification of internal company recommendations, resulting in more disagreements and internal conflicts, delaying the pace of corporate decision-making systems. Almazan and Suarez [7] showed that the reason why female directors have a negative impact on the company's value is mainly due to the over-regulation of female directors. It believes that when corporate governance is above a certain value, strengthening supervision will reduce the company's value. Adams and Ferreira [8], [9] used the 1939 US listed companies from 1996 to 2003 as samples to empirically analyze the impact of female executives on corporate governance and company value. The study found female directors have improved the company's governance, but have had a significant negative impact on corporate performance (TobinQ and ROA). Kakabadse et al. [10] use 30 companies with women directors in the United Kingdom, the United States, and investigate the relationship between gender in the boardroom and corporate governance. Their findings indicate that the presence of a minority of women on the board has an insignificant effect on board performance.

In order to find the answer to the question "Do female directors have an impact on corporate performance?" , we select the methodology and empirical data as follows.

\section{Methodology AND Data}

The standard linear regression model assumes that the parameters of the model do not vary across observations. Despite this assumption, regime shift, the changing of parameters at dates in the sample period, plays an empirically relevant role in the analysis. Accordingly, there has been a large volume of work targeted at developing testing and estimation methodologies for regression models which allow for structural change. There are different perspectives on the threshold regression model. Tong (1978) first proposed Threshold auto-regression model (TAR), Tong and Lim [11] subsequently revised this model and applied it to the nonlinear data, the regression model is adjudged by the thresholds to the interval where the threshold values are different. Hansen [12]-[14] proposed the threshold regression model to test whether the influential direction and degree of independent variables on the dependent variable are consistent. The threshold regression model automatically detects the threshold value and divides the data into two subsamples. The specific independent variable then has a different interpretation in the corresponding thresholds. The Panel Threshold model developed by Hansen [12]-[14] uses the threshold variable to determine the data breakpoints which are then used to estimate the appropriate values of the threshold variable. The method helps to avoid the shortage of methods that are commonly used to subjectively determine partition points. Bai and Perron [15] developed the methodology for estimating multiple breakpoints in a regression model that allows for serially correlated disturbances. Bai and Perron [16] conducted extensive simulation analysis to the scale and efficacy of the test and provided the critical values for empirical applications.

Therefore, in addition to using the panel regression model, this study validates the factors that may affect the profitability of bank, and further uses the threshold regression model proposed by Hansen, Bai and Perron to test whether there is an asymmetric effect on how female directors influence banking performance.

\section{A. Threshold Regression Model}

Hansen [12] designed the two-stage least square model for panel data. The first stage sets the threshold value $(\tau)$, and the sum of squared errors (SSE) are obtained individually by the least squares method; in the second stage, the sum of squared errors is used to inversely calculate the estimated threshold $(\tau)$. After obtaining the estimated threshold value, the threshold system can be further used to calculate the regression system of each interval for performing the result analysis. The model is as follows:

For the observations in regime $j=0,1, \cdots, n$ the specification of linear regression is as:

$$
y_{t}=\alpha+X_{\mathrm{t}}^{\prime} \beta_{\mathrm{j}}+\varepsilon_{\mathrm{t}}
$$

where the $\mathrm{X}$ variables are those whose parameters vary across regimes. Suppose that there is an observable threshold variable $\mathrm{q}_{\mathrm{t}}$ and strictly increasing threshold values $\left(\tau_{1}<\tau_{2} \ldots<\tau_{n}\right)$ such that the observations in regime $\mathrm{j}$ if and only if:

$$
\tau_{j} \leq q_{t}<\tau_{j+1}
$$

The single threshold, two regime model is:

$$
\begin{gathered}
y_{t}=\alpha+X_{t}^{\prime} \beta_{1}+\varepsilon_{t} \quad \text { if }-\infty \leq q_{t}<\tau_{j} \\
y_{t}=\alpha+X_{t}^{\prime} \beta_{2}+\varepsilon_{t} \quad \text { if } \tau_{j} \leq q_{t}<\infty
\end{gathered}
$$

Using the indicator function $\Pi($.) which takes the value 1 if the expression is true and 0 otherwise and defining $\Pi_{j}\left(q_{t}, \tau\right)=\Pi\left(\tau_{j} \leq q_{t}<\tau_{j+1}\right) \quad, \quad$ the $n+1$ individual regime specifications can be combined into the multi-threshold, $n$ regime model:

$$
y_{t}=\alpha+\sum_{j=1}^{n} \Pi_{j}\left(q_{t}, \tau\right)+X_{t}^{\prime} \delta_{j}+\varepsilon_{t}
$$




\section{B. Data Source and Variables}

The data for the empirical study is based on the Taiwanese commercial bank listed on the market. The sample period is from the first quarter of 1999 to the second quarter of 2019. The relevant information is from the Taiwan Economic Journal (TEJ) database, a total of 35 listed banks are initially obtained. Since the threshold regression model is applied to balanced panel data, the sample bank will be eliminated if its data is insufficient. After removing the sample banks with insufficient data, a total of 26 Taiwan commercial banks with 2510 observations are selected for empirical analysis. The data includes the return on assets, the ratio of independent directors, the size of the directorship, the female directors in the board, and the control variables such as debt ratio, capital adequacy ratio, market share, revenues, nonperforming loans, loans, deposits and equity.

The Blau Index [17] that gives a measure of the distance of equality between women and men used to empirically test whether greater gender diversity in the board of directors is related to banks' performance.

$$
\text { Blau }=\left[1-\sum_{g=1}^{G} P_{g}^{2}\right] \times 100
$$

where $P$ is the proportion of male and female directors on the bank's board and $g$ is the gender. The maximum value for this metric is 50 when there are exactly $50 \%$ of women and $50 \%$ of men in gender diversity indicator. The higher value of Blau index presents the more female directors in board.

The total assets of a bank is used as the threshold variables for exploring the nonlinearity relationship between female directors and the bank's performance. The definition of all variables used in the analysis can be found in Table I.

TABLE I: VARIABLE DEFINITIONS

\begin{tabular}{|c|c|}
\hline Variable & Definition \\
\hline \multicolumn{2}{|c|}{ Profitability (PRF) } \\
\hline $\mathrm{ROAA}_{i t}$ & $\begin{array}{l}\text { Return on assets before interest after taxes at time } t \text { of } i \\
\text { bank. }\end{array}$ \\
\hline $\mathrm{ROAB}_{i t}$ & Return on assets before interest, taxes and depreciation. \\
\hline $\mathrm{ROAC}_{i t}$ & $\begin{array}{l}\text { Return on assets before interest, depreciation, and after } \\
\text { taxes. }\end{array}$ \\
\hline \multicolumn{2}{|c|}{ Board structure (BSE) } \\
\hline$B A U_{i t}$ & $\begin{array}{l}\text { Measure of board gender diversity. The maximum value } \\
\text { for Blau measurement is } 50 \text {. }\end{array}$ \\
\hline$I N D_{i t}$ & $\begin{array}{l}\text { Independent director is the ratio of number of } \\
\text { independent directors to total board members }\end{array}$ \\
\hline$B D S_{i t}$ & $\begin{array}{l}\text { The power of Board is the ratio of number of shares held } \\
\text { by board members to total outstanding shares }\end{array}$ \\
\hline \multicolumn{2}{|c|}{ Threshold $(\tau)$} \\
\hline$L N(T A)_{i t}$ & Natural log of total assets as at the end of period. \\
\hline \multicolumn{2}{|c|}{ Control (CTR) } \\
\hline$B I S_{i t}$ & $\begin{array}{l}\text { Capital adequacy ratio, is the ratio of total capital to total } \\
\text { weighted risk assets. This ratio reflects the extent to } \\
\text { which a bank can bear the loss by its own capital. }\end{array}$ \\
\hline$D B T_{i t}$ & $\begin{array}{l}\text { The debt ratio is calculated as total liabilities as } \\
\text { percentage of total assets }\end{array}$ \\
\hline$M S R_{i t}$ & $\begin{array}{l}\text { The ratio of the revenue at time } t \text { of } i \text { bank to total } \\
\text { revenues of sample banks }\end{array}$ \\
\hline$R E V_{i t}$ & The ratio of total revenues to total assets. \\
\hline$E F F_{i t}$ & $\begin{array}{l}\text { The ratio of the non-interest expense to total assets at } \\
\text { time t of } i \text { bank }\end{array}$ \\
\hline$N P L_{i t}$ & $\begin{array}{l}\text { The nonperforming loans ratio measures the rate at which } \\
\text { a bank's loans are not repaid. }\end{array}$ \\
\hline$D T D_{i t}$ & The ratio of interbank deposits to total liabilities. \\
\hline$E T A_{i t}$ & The ratio of equity to total assets. \\
\hline$N I T_{i t}$ & The ratio of non-interest revenue to total assets. \\
\hline$L T A_{i t}$ & The ratio of loans to total assets. \\
\hline
\end{tabular}

In order to examine how women on board affect banks' performance, we establish an empirical model as follows:

$$
\mathrm{PRF}_{i t}=\left\{\begin{array}{c}
\alpha+\beta_{1} B A U+\beta_{2} B A U^{2}+\beta_{3} B A U * B I S+\beta_{4} B A U^{2} * B I S \\
+\beta_{5} I N D+\beta_{6} B D S+\delta_{1} M S R+\delta_{2} L N(T A)+\delta_{3} D B T+\delta_{4} R E V \\
+\delta_{5} N I T+\delta_{6} E F F+\delta_{7} N P L+\delta_{8} D T D+\delta_{9} L T A+\delta_{10} E T A+\varepsilon_{i t}
\end{array}\right.
$$

Profitability variables (PRF) including ROAA, ROAB, and ROAC are as explained in Table I. These five regression models include variables of board structure (BSE) and Control (CTR). The multi-threshold, $\mathrm{n}$ regime model is rewritten as follows:

$$
P R F_{i t}=\alpha+\left[\beta_{j}(B S E)_{i t}^{\prime}+\delta_{j}(C T R)_{i t}^{\prime}\right] \cdot \sum_{j=1}^{n} \Pi_{j}\left(T A_{t}, \tau\right)+\varepsilon_{i t}
$$

In order to understand whether the capital adequacy ratio (BIS) affect the relationship between gender diversity and bank performance, that may increase or decrease the relationship between the two, we also add three interaction factors including $\mathrm{BAU}^{2}, \mathrm{BAU} * \mathrm{BIS}$, and $\mathrm{BAU}^{2} * \mathrm{BIS}$ that make the effect of gender diversity change with the characteristics of capital adequacy ratio in all models.

\section{EMPIRICAL RESULTS}

The summary statistics of variables are summarized in Table II. As the values in Table II indicate, the mean and median BAU index during the sample period is around 16.6 percent, meaning that one out of six board members being woman. The mean of board size is 14.6 members, corresponding to two or three female directors on the bank board. However, the maximum proportion of women is high at 48.4 percent, while the minimum value is 0 percent. The imbalance of gender diversity on board across sample banks should be noted.

The average return on assets (ROAA, ROAB, and ROAC) is around 0.1 percent, the maximum are around 1.1 percent, and the minimum is around -2.5 percent, indicating that the difference in return on assets is quite large among banks. The mean and median bank size (LNTA) are 20.379 and 20.481, respectively, indicating that the size of Taiwan's commercial banks is fairly average.

For the control variables, the non-performing loans ratio is not average among banks with its standard deviation of 2.142 percent. The mean and median of debt ratio (DBT) are 92.91 and 93.62, respectively, indicating that the liabilities of commercial banks are quite heavy.

TABLE II: SUMMARY STATISTICS

\begin{tabular}{lrrrrr}
\hline Variable & Mean & Median & Maximum & Minimum & Std. Dev. \\
\hline ROAA & 0.093 & 0.140 & 1.000 & -2.520 & 0.330 \\
ROAC & 0.119 & 0.160 & 1.270 & -3.290 & 0.387 \\
ROAB & 0.101 & 0.140 & 1.100 & -2.480 & 0.317 \\
BAU & 16.634 & 16.529 & 48.443 & 0.000 & 12.596 \\
BIS & 9.988 & 11.350 & 19.840 & 0.000 & 4.883 \\
IND & 2.006 & 2.000 & 5.000 & 0.000 & 1.474 \\
BDS & 14.559 & 13.000 & 26.000 & 6.000 & 4.385 \\
LN(TA) & 20.379 & 20.481 & 22.350 & 17.665 & 0.978 \\
MSR & 0.034 & 0.027 & 0.159 & 0.002 & 0.026 \\
DBT & 92.910 & 93.620 & 99.170 & 50.550 & 3.750 \\
REV & 0.008 & 0.007 & 0.022 & 0.001 & 0.003 \\
EFF & 0.001 & 0.000 & 0.043 & -0.005 & 0.002 \\
NPL & 1.535 & 0.730 & 16.020 & 0.000 & 2.142 \\
DTD & 0.009 & 0.000 & 0.191 & 0.000 & 0.021 \\
ETA & 0.071 & 0.064 & 0.495 & 0.008 & 0.038 \\
NIT & 0.002 & 0.002 & 0.015 & -0.003 & 0.001 \\
LTA & 0.198 & 0.196 & 0.590 & 0.000 & 0.200 \\
\hline
\end{tabular}


To test for unknown thresholds of the relationship between LN(TA) and profitability variables, the basic estimation setup for the breakpoint testing and regression [12]-[14]. In essence, threshold regression can be regarded as a breakpoint least squares regression, where the data is reordered according to the breakpoints of the threshold variable. Table III presents the results for sequentially determined thresholds using the Sup-F test statistics.

\begin{tabular}{|c|c|c|c|}
\hline Threshold Test & $\begin{array}{l}\text { ROAA } \\
\text { F value }\end{array}$ & $\begin{array}{l}\text { ROAB } \\
\text { F value }\end{array}$ & $\begin{array}{l}\text { ROAC } \\
\text { F value }\end{array}$ \\
\hline 0 vs. $1 *$ & $30.02^{* * * *}$ & $21.81^{* * *}$ & $21.33^{* * * *}$ \\
\hline 1 vs. $2 *$ & $16.10^{\text {*** }}$ & $15.85^{* * * *}$ & $18.37^{\text {*** }}$ \\
\hline 2 vs. $3 *$ & $5.65^{* *}$ & $6.14^{* *}$ & $6.63^{* *}$ \\
\hline 3 vs. $4 *$ & $5.87^{* *}$ & $5.39^{*}$ & $6.18^{* *}$ \\
\hline Threshold value: & ROAA & ROAB & ROAC \\
\hline Threshold 1 & 19.3540 & 19.3540 & 19.3540 \\
\hline Threshold 2 & 20.8811 & 20.8811 & 20.8811 \\
\hline Threshold 3 & 20.2963 & 20.2963 & 20.2963 \\
\hline Threshold 4 & 21.2032 & 21.2032 & 21.2032 \\
\hline
\end{tabular}

Note: $* * * * *$ and $*$ indicate significance at the $1 \%, 5 \%$, and $10 \%$ levels, respectively.

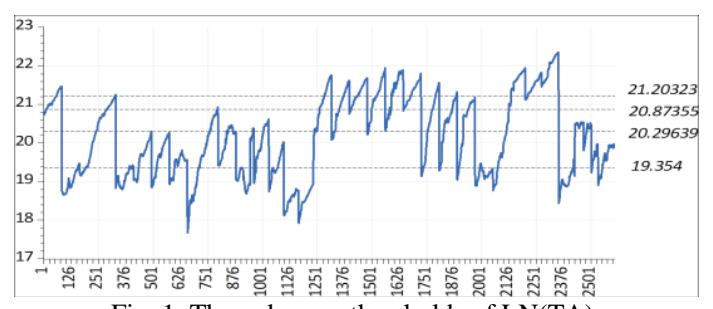

Fig. 1. The unknown thresholds of LN(TA).

Table III and Fig. 1 report that the threshold values of LN(TA) for ROA are 19.354, 20.881, 20.296 and 21.203, the threshold values for LSP are 24.86, 12.77, and 5.93, and the threshold values for LPD are 19.34, 8.65, 4.64, and 6.95. Basing on the threshold values detected by the method of Bai-Perron [16], the estimation results of the panel regression and the model (6) are summarized and presented in Table IV, Table V, and Table VI.

When the proxy variable of profitability is ROA, including ROAA (Return on assets before interest after taxes), ROAB (Return on assets before interest, taxes and depreciation, and ROAC (Return on assets before interest, depreciation, and after taxes), the direct effect of Blau value (BIS) in Table IV, Table V, and Table VI is negative and not significant within panel regression framework. However this effect turns into positive signs when LN(TA) $<19.354$ (relative to bank with total assets of TW $\$ 254$ billion) and keep positive sign up to $\mathrm{LN}(\mathrm{TA})<21.20323$ (relative to bank with total assets of TW $\$ 1616$ billion), indicating that the "direct effect" of female directors on bank profitability is positive for banks with total assets less than TW $\$ 254$ billion. Basing on the squared Blau value (BIS) and the interaction with the capital adequacy ratios, it is clear that the marginal effect of additional gender diversity depends on its current level and the total capital of the bank. When considering Blau value (BIS) as the influencing factor, the coefficient of effect is not consistent. It even completely changes the influential sign of the relationship between bank female directors and profitability. That is to say, when banks consider the capital adequacy ratio, the influence of female directors on ROA will disappear and reduce their profitability. Except for the influential sign of IND, NPL, DBT, DTD and LTA on ROA are mostly consistent in both panel model and threshold model, the sign of BDS, MSR, TA, REV, EFF, ETA, and NIT indicate the existence of nonlinearity.

Women's representation on board is a choice that board make, and that bank profitability is influenced by this choice. The results demonstrate that after controlling for bank size and capital adequacy ratio, there are changes in the positive effect that female boardroom representation has on performance measures included in this study.

As the company's highest authority, the board plays a vital role in determining the direction of the company's development, safeguarding the interests of shareholders and accountability. The board of directors including women can do this better. This study found that gender diversity in the board can increase profitability while enhancing internal controls. However, the case for gender diversity on bank boards rests on a sense of fairness on what in essence for more gender diversity.

TABLE IV: THE ASYMMETRIC EFFECT OF GENDER DIVERSITY ON ROAA

\begin{tabular}{|c|c|c|c|c|c|c|}
\hline & Panel & $\mathrm{T}<19.354$ & $19.354 \leqq \mathrm{~T}<20.2963$ & $20.2963 \leqq \mathrm{~T}<20.8735$ & $20.8735 \leqq \mathrm{~T}<21.2032$ & $21.2032 \leqq \mathrm{~T}$ \\
\hline$\alpha$ & 65.5126 & 603.8284 & 90.0568 & -92.7298 & 15.0611 & -24.6409 \\
\hline BAU & -0.0036 & $0.0253^{* * *}$ & 0.0087 & 0.0053 & 0.0066 & -0.0059 \\
\hline $\mathrm{BAU}^{2}$ & 0.0001 & $-0.0002^{*}$ & -0.0002 & 0.0002 & 0.0000 & 0.0001 \\
\hline BAU*BIS & 0.0000 & $-0.0016^{* * *}$ & $-0.0008^{*}$ & -0.0007 & $-0.0022^{* * *}$ & 0.0003 \\
\hline $\mathrm{BAU}^{2 *} \mathrm{BIS}$ & -0.0000 & 0.0000 & 0.0000 & -0.0000 & $0.0000^{* *}$ & -0.0000 \\
\hline IND & $-0.0176^{* *}$ & $-0.1044^{* * *}$ & -0.0163 & -0.0209 & -0.0033 & 0.0177 \\
\hline BDS & $0.0085^{\text {**** }}$ & 0.0049 & $0.0138^{* * * *}$ & $-0.0273^{* * *}$ & -0.0048 & -0.0060 \\
\hline MSR & $-4.1508^{* * *}$ & $50.2100^{* * *}$ & $10.1367^{* * *}$ & -0.5889 & $7.1247^{* * * *}$ & -1.5199 \\
\hline LN(TA) & $0.2273^{* * *}$ & $-0.5188^{* * *}$ & -0.0525 & $0.3510^{* * *}$ & $-0.3552^{*}$ & 0.0387 \\
\hline DBT & -0.7002 & -5.9391 & -0.8921 & 0.8626 & -0.0710 & 0.2402 \\
\hline REV & $17.3555^{* * *}$ & $-19.8880^{*}$ & $-16.3205^{* *}$ & -9.6453 & -13.8524 & 10.2768 \\
\hline EFF & $-31.9337^{* * *}$ & $28.4644^{* * *}$ & 9.7383 & $46.9371^{* *}$ & $-42.5630^{*}$ & 23.3240 \\
\hline NPL & $-0.0907^{* * *}$ & $-127.9320^{* * *}$ & 1.5963 & -4.0029 & $-15.2979 *$ & -13.6854 \\
\hline DTD & $-1.8835^{* * *}$ & $-0.0841^{* * *}$ & $-0.0471^{* * *}$ & $-0.0172^{*}$ & $-0.2223^{* * * *}$ & -0.0099 \\
\hline ETA & -69.8447 & $-1.3702^{* *}$ & -0.4333 & $-1.6277^{* *}$ & $7.2077^{* * * *}$ & -0.5382 \\
\hline NIT & $20.7653^{* *}$ & -0.0856 & -0.0616 & -0.0871 & $0.1609^{*}$ & 0.0131 \\
\hline LTA & 0.0032 & -594.3069 & -86.0958 & 84.2760 & -8.9240 & 24.3398 \\
\hline Cross-section fixed & $\mathrm{Y}$ & $\mathrm{N}$ & $\mathrm{N}$ & $\mathrm{N}$ & $\mathrm{N}$ & $\mathrm{N}$ \\
\hline Period fixed & $\mathrm{Y}$ & $\mathrm{N}$ & $\mathrm{N}$ & $\mathrm{N}$ & $\mathrm{N}$ & $\mathrm{N}$ \\
\hline R-squared & 0.487 & 0.627 & 0.627 & 0.627 & 0.627 & 0.627 \\
\hline Adj. R-squared & 0.452 & 0.608 & 0.608 & 0.608 & 0.608 & 0.608 \\
\hline
\end{tabular}

Note: $* * *, * *$ and $*$ indicate significance at the $1 \%, 5 \%$, and $10 \%$ levels, respectively. 
TABLE V: THE ASYMMETRIC EFFECT OF GENDER DIVERSITY ON ROAB

\begin{tabular}{|c|c|c|c|c|c|c|}
\hline & Panel & $\underline{\mathrm{T}<19.2486}$ & $19.2486 \leqq \mathrm{~T}<20.2963$ & $20.2963 \leqq \mathrm{~T}<20.8771$ & $20.8771 \leqq \mathrm{~T}<21.2032$ & $21.2032 \leqq \mathrm{~T}$ \\
\hline $\bar{\alpha}$ & 158.7754 & $772.9535^{*}$ & 32.6461 & 206.4829 & -3.2637 & -16.2344 \\
\hline BAU & -0.0044 & $0.0205^{* * * *}$ & $0.0139^{* * *}$ & -0.0001 & 0.0053 & -0.0125 \\
\hline $\mathrm{BAU}^{2}$ & 0.0001 & -0.0001 & -0.0002 & 0.0005 & 0.0000 & 0.0003 \\
\hline BAU*BIS & 0.0001 & $-0.0011^{* *}$ & $-0.0009^{* *}$ & -0.0002 & $-0.0020^{* * *}$ & 0.0007 \\
\hline $\mathrm{BAU}^{2} * \mathrm{BIS}$ & -0.0000 & 0.0000 & 0.0000 & $-0.0000^{*}$ & $0.0000^{*}$ & -0.0000 \\
\hline IND & $-0.0265^{* * *}$ & $-0.1018^{* * * *}$ & $-0.0184^{*}$ & $-0.0418^{* * *}$ & -0.0039 & 0.0056 \\
\hline BDS & $0.0119^{* * *}$ & 0.0024 & $0.0079^{\text {*** }}$ & $-0.0232^{* * *}$ & -0.0048 & -0.0013 \\
\hline MSR & $-4.0378^{* * *}$ & $38.7529^{* * *}$ & $14.1418^{* * * *}$ & 0.0675 & $7.7592^{* * *}$ & -1.1356 \\
\hline LN(TA) & $0.2149^{* * *}$ & $-0.6978^{* * *}$ & -0.0810 & $0.3932^{\text {*** }}$ & $-0.3532^{*}$ & -0.0176 \\
\hline DBT & -1.6304 & $-7.5959^{*}$ & -0.3124 & -2.1382 & 0.1115 & 0.1673 \\
\hline REV & $22.9756^{* * * *}$ & 10.0687 & $-29.3742^{* * * *}$ & 0.5939 & -13.7772 & 11.8264 \\
\hline EFF & $-31.2446^{* * *}$ & $22.9823^{* *}$ & 14.8044 & $35.0583^{*}$ & $-43.5973^{*}$ & 19.2518 \\
\hline NPL & $-0.0878^{* * *}$ & $-120.6682^{* * *}$ & -3.1216 & 1.6805 & $-15.7111^{*}$ & -13.3790 \\
\hline DTD & $-1.6103^{* * *}$ & $-0.0953^{* * *}$ & $-0.0394^{* * *}$ & $-0.0194^{* *}$ & $-0.2210^{* * * *}$ & -0.0177 \\
\hline ETA & -163.7669 & 0.0789 & $-1.6010^{* * * *}$ & $-1.3744^{* *}$ & $7.1071^{\text {*** }}$ & -0.2311 \\
\hline NIT & $18.7452^{* *}$ & -0.0873 & 0.0437 & -0.0858 & $0.1590^{*}$ & 0.0006 \\
\hline LTA & 0.0118 & $-762.2793^{*}$ & -26.7245 & -217.5451 & 9.6759 & 17.5334 \\
\hline Cross-section fixed & $\mathrm{Y}$ & $\mathrm{N}$ & $\mathrm{N}$ & $\mathrm{N}$ & $\mathrm{N}$ & $\mathrm{N}$ \\
\hline Period fixed & $\mathrm{Y}$ & $\mathrm{N}$ & $\mathrm{N}$ & $\mathrm{N}$ & $\mathrm{N}$ & $\mathrm{N}$ \\
\hline R-squared & 0.466 & 0.584 & 0.584 & 0.584 & 0.584 & 0.584 \\
\hline Adj. R-squared & 0.430 & 0.562 & 0.562 & 0.562 & 0.562 & 0.562 \\
\hline
\end{tabular}

Note: $* * *, * *$ and $*$ indicate significance at the $1 \%, 5 \%$, and $10 \%$ levels, respectively.

TABLE VI: THE ASYMMETRIC EFFECT OF GENDER DIVERSITY ON ROAC

\begin{tabular}{|c|c|c|c|c|c|c|}
\hline & $\underline{\text { Panel }}$ & $\underline{T<19.2486}$ & $19.2486 \leqq \mathrm{~T}<20.2963$ & $20.2963 \leqq \mathrm{~T}<20.8771$ & $20.8771 \leqq \mathrm{~T}<21.2032$ & $21.2032 \leqq \mathrm{~T}$ \\
\hline$\alpha$ & 177.2855 & 768.8041 & 65.4852 & 296.3912 & 11.3310 & -53.6345 \\
\hline BAU & -0.0063 & $0.0242^{* * *}$ & $0.0167^{* * *}$ & 0.0032 & 0.0082 & -0.0155 \\
\hline $\mathrm{BAU}^{2}$ & 0.0002 & -0.0001 & -0.0003 & 0.0005 & 0.0000 & 0.0004 \\
\hline BAU*BIS & 0.0003 & $-0.0011^{* *}$ & $-0.0010^{*}$ & -0.0005 & $-0.0027^{* * *}$ & 0.0009 \\
\hline $\mathrm{BAU}^{2 *} \mathrm{BIS}$ & -0.0000 & 0.0000 & 0.0000 & -0.0000 & $0.0000^{*}$ & -0.0000 \\
\hline IND & $-0.0313^{* * *}$ & $-0.1150^{* * * *}$ & -0.0197 & $-0.0519^{* * *}$ & -0.0079 & 0.0054 \\
\hline BDS & $0.0143^{* * *}$ & 0.0064 & $0.0095^{* *}$ & $-0.0315^{* * *}$ & -0.0038 & -0.0013 \\
\hline MSR & $-5.5671^{* * *}$ & $44.8363^{\text {*** }}$ & $16.8712^{* * *}$ & 0.2239 & $10.0292^{* * * *}$ & -1.3715 \\
\hline LN(TA) & $0.2720^{\text {*** }}$ & $-0.8325^{* * *}$ & -0.0924 & $0.5144^{* * *}$ & $-0.4564^{*}$ & -0.0271 \\
\hline DBT & -1.8270 & -7.5293 & -0.6391 & -3.0599 & -0.0121 & 0.5436 \\
\hline REV & $32.9917^{* * *}$ & 14.3244 & $-31.0425^{* * *}$ & 0.5940 & -14.3232 & 16.1173 \\
\hline $\mathrm{EFF}$ & $-38.8585^{* * *}$ & $23.7630^{*}$ & 13.7281 & $39.7794 *$ & $-63.5751^{* *}$ & 19.2481 \\
\hline NPL & $-0.1056^{* * *}$ & $-145.3509^{* * *}$ & -4.3162 & 6.8232 & $-18.0937^{*}$ & -14.6032 \\
\hline DTD & $-2.0126^{* * *}$ & $-0.1093^{* * *}$ & $-0.0472^{* * *}$ & $-0.0224^{* *}$ & $-0.2879^{* * *}$ & -0.0217 \\
\hline ETA & -183.6777 & 0.0237 & $-2.1277^{* * *}$ & $-1.7994^{* *}$ & $9.3433^{* * * *}$ & -0.3065 \\
\hline NIT & $18.7461^{*}$ & -0.1122 & 0.0529 & -0.1200 & $0.2004^{*}$ & -0.0071 \\
\hline LTA & 0.0026 & -756.1758 & -58.7736 & -310.7227 & -2.8910 & 55.1495 \\
\hline Cross-section fixed & $\mathrm{Y}$ & $\mathrm{N}$ & $\mathrm{N}$ & $\mathrm{N}$ & $\mathrm{N}$ & $\overline{\mathrm{N}}$ \\
\hline Period fixed & $\mathrm{Y}$ & $\mathrm{N}$ & $\mathrm{N}$ & $\mathrm{N}$ & $\mathrm{N}$ & $\mathrm{N}$ \\
\hline R-squared & 0.452 & 0.587 & 0.587 & 0.587 & 0.587 & 0.587 \\
\hline Adj. R-squared & 0.414 & 0.566 & 0.566 & 0.566 & 0.566 & 0.566 \\
\hline
\end{tabular}

\section{CONCLUSIONS}

This paper uses the panel data of 26 Taiwanese commercial banks during the period of 1999-2019 to examine the effect of gender diversity of bank board on profitability. The main purpose of the study is to explain whether bank female directors would help banks to make a profit? Which factors can influence bank profitability through the degree of gender diversity? Within the framework of different bank sizes, do the relationship between the bank's female directors and the bank's profitability change? In addition, in order to make up for the shortcomings of the previous literature on the influencing factors, this study further explores the impact of bank capital adequacy ratio as well as total assets.

We use the panel threshold regression for empirical results and find that: First, bank female directors have inconsistent effect on bank profits; Second, banks with high capital adequacy ratio will weaken or even reduce the positive relationship between bank female directors and bank profitability; Third, banks with total assets higher than TW $\$ 1616$ billion have the opposite effect on ROA relative to the rest of banks. Finally, the results of threshold regression prove that the impact of gender diversity on bank profitability is linearity that is more complicated than a direct effect suggests.

\section{CONFLICT OF INTEREST}

The authors declare that there is no conflict of interest regarding the publication of this article.

\section{AUTHOR CONTRIBUTIONS}

T. Thanh Binh Nguyen: Conceptualization, Formal analysis, Methodology, Supervision, Writing - review \& editing. Zi-Yu Chen: Data curation, Writing - original draft.

\section{REFERENCES}

[1] R. D. Adler, "Women in the executive suite correlate to high profits," Harvard Business Review, vol. 79, no. 3, pp. 30-32, 2001.

[2] D. A. Carter, B. J. Simkins, and W. G. Simpson, "Corporate governance, board diversity, and firm value," Financial Review, vol. 38, no. 1, pp. 33-53, 2003.

[3] K. Campbell and A. Mínguez-Vera, "Gender diversity in the boardroom and firm financial performance," Journal of Business Ethics, vol. 83, no. 3, pp. 435-451, 2008. 
[4] C. Rose, "Does female board representation influence firm performance? The Danish evidence," Corp. Gov.: Int. Rev., vol. 15, no. 2, pp. 404-413, 2007.

[5] M. Bennouri, T. Chtioui, H. Nagati, and M. Nekhili, "Female board directorship and firm performance: What really matters?" Journal of Banking \& Finance, vol. 88, pp. 267-291, 2018.

[6] D. C. Hambrick and E. M. Jackson, "Outside directors with a stake: The linchpin in improving governance," California Management Review, vol. 42, no. 4, pp. 108-127, 2000.

[7] A. Almazan and J. Suarez, "Entrenchment and severance pay in optimal governance structures," The Journal of Finance, vol. 58, no. 2, pp. 519-547, 2003.

[8] R. B. Adams and D. Ferreira, "Women in the boardroom and their impact on governance and performance," Journal of Financial Economics, vol. 94, pp. 291-309, 2009.

[9] R. B. Adams and H. Mehran, "Bank board structure and performance: Evidence for large bank holding companies," Journal of Financial Intermediation, vol. 21, pp. 243-267, 2012.

[10] N. K. Kakabadse, C. Figueira, K. Nicolopoulou, J. Hong Yang, A. P. Kakabadse, and M. F. Özbilgin, "Gender diversity and board performance: Women's experiences and perspectives," Human Resource Management, vol. 54, no. 2, pp. 265-281, 2015.

[11] H. Tong and K. S. Lim, "Threshold autoregression, limit cycles and cyclical data," Journal of the Royal Statistical Society. Series B (Methodological), vol. 42, pp. 245-292, 1980.

[12] B. E. Hansen, "Threshold effects in non-dynamic panels: Estimation, testing and inference," Journal of Econometrics, vol. 93, pp. 345-368, 1999.

[13] B. Hansen, "Testing for Structural change in conditional models," Journal of Econometrics, vol. 97, pp. 93-115, 2000.

[14] B. Hansen, "Threshold autoregression in economics," Statistics and Its Interface, vol. 4, pp. 123-127, 2011.
[15] J. Bai and P. Perron, "Estimating and testing linear models with multiple structural changes," Econometrica, vol. 66, pp. 47-78, 1998.

[16] J. Bai and P. Perron, "Computation and analysis of multiple structural change models," Journal of Applied Econometrics, vol. 18, pp. 1-22, 2003.

[17] P. M. Blau, Inequality and Heterogeneity, New York, NY: Free Press, 1977.

Copyright (C) 2020 by the authors. This is an open access article distributed under the Creative Commons Attribution License which permits unrestricted use, distribution, and reproduction in any medium, provided the original work is properly cited ( $\underline{\mathrm{CC} \mathrm{BY} \mathrm{4.0}})$.

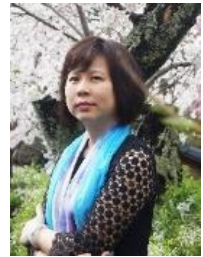

T. Thanh Binh Nguyen received her Ph.D degree in finance from Feng Chia University in 2007 and has been the assistant professor of Chaoyang University of Technology since 2008. Nguyen's research mainly focuses on international economics, finance, and management.

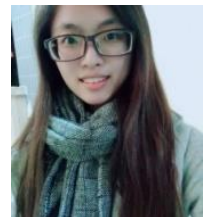

$\mathrm{Zi}-Y \mathbf{u}$ Chen is an MA candidate in accounting at Chaoyang University of Technology. 